Nippon Suisan Gakkaishi $\quad$ 79(1), 78 (2013)

\title{
シンポジウム記録 沿岸資源の増殖・管理と分子生物学的手法によるモニタリング
}

\section{II-1． 瀬戸内海におけるトラフグの放流効果と 再生産寄与}

\author{
片町太輔 \\ 独水産総合研究センター瀬戸内海区水産研究所
}

II-1. Stocking effectiveness and reproductive success of hatchery-reared Tiger puffer Takifugu rubripes in the Seto Inland Sea

DAISUKE KATAMACHI

National Research Institute of Fisheries and Environment of Inland Sea, Fisheries Research Agency, Hatsukaichi, Hiroshima 739-0452, Japan

我が国では，資源量の増大を目的として多くの水産対 象種の人工種苗が天然海域に放流されている。これま で，標識採捕調査によって，放流後の人工種苗の回収率 や放流事業の費用対効果について多くの知見が蓄積され てきた。その一方で，人工種苗の放流がぞれほど資源量 の増大に貢献したかについては評価が難しく, 評価方法 についても模索段階である。人工種苗それ自体が資源に ぞの程度添加され，放流後にどの程度再生産へ寄与して いるのかについて把握することは, 今後の資源管理方策 を考える上で極めて重要である。ここでは, 瀬戸内海西 部におけるトラフグを対象に, 人工種苗の資源への添加 および再生産への寄与について我々がこれまで蓄積して きた知見を紹介し，これからの研究で重点を置くべきこ とについて提案したい。

\section{1. 瀬戸内海西部におけるトラフグ人工種苗の資源への} 添加

瀬戸内海西部では，2002 2010 年の 7 月に背部へ焼 印標識が施された $75,000 〜 266,000$ 尾（平均 170,000 尾）のトラフグ人工種苗が毎年放流された ${ }^{1,2)}$ 。人工種 苗の多くは独水産総合研究センター瀬戸内海区水産研究 所屋島庁舎（屋島庁舎）で養成された種苗生産用親魚か ら生産された個体である。放流後から 12 月までを調査 期間として, 当海域での人工種苗の資源への添加の割合 （添加効率）について推定を行った。その結果, 添加効
率は 2002～2009 年に 2 18\% で推移したと推定され た。また， 0 歳魚の資源尾数に占める人工種苗の割合は 1〜34\% で推移したと推定された。

\section{2. 瀬戸内海西部におけるトラフグ人工種苗の再生産へ の寄与}

近年, 瀬戸内海西部では, トラフグの産卵親魚群に回 帰した人工種苗が高い割合で混入していることが観察さ れ, 再生産に寄与している可能性が指摘されていた。こ のことを検証するため, 2006 年の $4 \sim 5$ 月に採集された 回帰した人工種苗, 生産記録から回帰した人工種苗の親 候補と考えられる屋島庁舎の種苗生産用親魚, 2006 年 の 8〜11月に採集された天然 0 歳魚を対象に DNA 分析 を行った。核 DNA のマイクロサテライト17ローカス による個体間の遺伝的類似性を算出した結果, 雌の種苗 生産用親魚と近縁な天然 0 歳魚が検出された。そし て, それらのミトコンドリア DNA 調節領域 (523 塩基) のハプロタイプは同一であった。これらのことから, 当 海域では, 人工種苗が再生産に寄与している可能性が高 いことが示唆された。

\section{3. 今後の展望}

瀬戸内海西部では, 人工種苗の添加効率が推定され, 回帰した人工種苗が再生産に寄与している可能性が高い ことが示唆された。今後は人工種苗の再生産への寄与に ついて定量的に評価する必要があるだろう。また，近 年, 当海域では天然加入が急激に減少し, 人工種苗が資 源量の下支えをしている状態である。資源量の増大のた めには, 天然加入の減少の解明とその対策も重要である と考えられる。

\section{文献}

1) 平成 17 年度都道府県連携促進事業報告書（瀬戸内海海域 トラフグ共同放流調查), 山口県水産研究センター, 大分 県農林水産研究センター水産試験場, 愛媛県中予水産試験 場. 2008.

2）栽培漁業資源回復等対策事業（平成 18-22 年度）総括報 告書, (社)全国豊かな海づくり推進協会. 2011. 